\title{
|ポリマーブレンド法によるナノカーボンの調製
}

\section{Preparation of nanocarbons using polymer blend technique}

\section{山洞輝和, 尾崎純一*, 大谷朝男}

Terukazu Sandou, Jun-ichi Ozaki* and Asao Oya

\section{1. はじめに}

“ナノカーボン”という語彙も市民権を得たようで, 以前のよう な新鮮さは感じられなくなった。しかし, 実用化となると話は別で, 必ずしも期待どおりには展開していないようである。安価なナ ノカーボンの大量供給がないから用途開発が進展しないのか, 用途 がないから量産が行われないのか！ 前者の色合いが濃いよう に思われるのだが。

ここで紹介するポリマーブレンドを活用する方法が, 即ナノカー ボン量産の救世主になるとは毛頭思っていない。むしろ,多様な 形状のナノカーボンをデザインし得るユニークな方法であること を読み取っていただければありがたい。そんなわけで，ナノサイ ズではないが, ユニークな形状のカーボンも一部取り上げた。標 題とは合致しないが, あらかじめご承知置き願いたい。この総説が きっかけとなって, 量産化に向けてトライしてみようという挑戦 者が 1 人でも現れてくれれば, 筆者らにとってこれこそ“望外の 喜び”である。内心こんな思惑もあるので, 本総説では実験を通 して得たノウハウ的な点についても，できる限り記述することに した。

\section{2. ポリマーブレンド法の基本概念}

ポリマーブレンド法の基本的な考え方を最初に知っておいて いただいたほうが，その後の話を理解しやすいと思われる。Fig.1 の模式図で説明しておこう。基本的には, 原料として 2 種類のポ

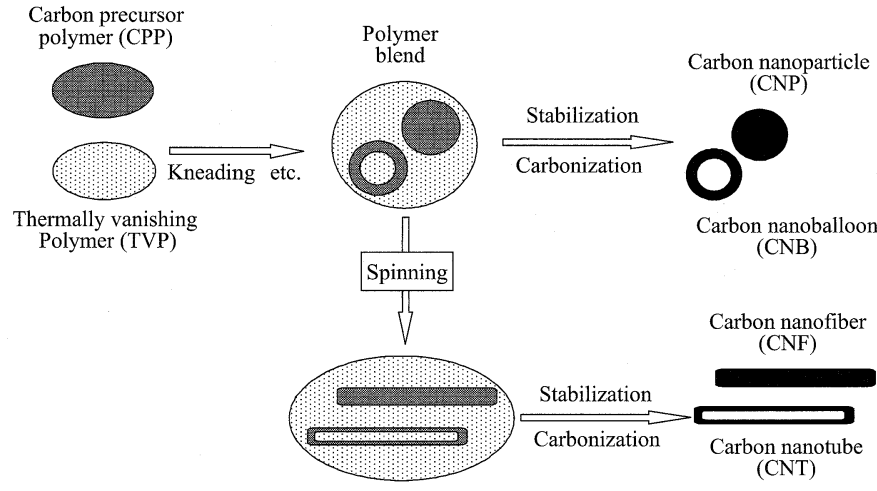

Fig.1 Fundamental concept of designing nanocarbons using the polymer blend technique.
リマーを使用する。1つは炭素前駆体ポリマー (Carbon Precursor Polymer：CPP）であり，ほかは加熱によって消失する熱消失性 ポリマー (Thermally Vanishing Polymer：TVP) である。両ポリ マーを用いてブレンドの構造, 厳密に言えばCPP の構造をデザイ ンする。Fig.1にはCPP粒子，およびCPP とTVP とからなるコア シェル粒子の例が示されている。デザイニングには機械混練な ど, 多様な手法を使用できる。ポリマーとしては, 加熱によって 溶融軟化するもののほうがデザインしやすい。

CPPが熱可塑性ということになると,そのまま炭素化した場合, デザインした構造が再び軟化溶融して崩壊してしまう。これを 避けるために, CPPの重縮合を進めて軟化溶融しないようにする。 すなわち不融化処理である1)。他方のTVPは, 同じ处理条件下に おいても熱消失性が維持されるポリマーでなければならない。

不融化処理に供したポリマーブレンド試料を炭素化すればTVP が消失し，その後にCPPの形状を引き継いだ炭素だけが残る。 Fig.1の上段には, カーボンナノ粒子 (CNP) とカーボンナノバル ーン (CNB) の例が示されている。TVPは2つの役割を有する。 1つは, デザインされたCPP間の融着防止であり，ほかはCNBの 例で見られる気孔形成材としての役割である。

ポリマーブレンドの紡系は, デザイニングの幅を拡大するうえ で効果的である。とりわけ有用なナノカーボンをデザインし得 る点で貴重である。紡糸によって, ポリマーブレンドの構造は一次 元に延伸されるので, Fig.1の下段のルートを辿るようになる。 CNPに代わってカーボンナノファイバ (CNF) が, CNB に代わっ てカーボンナノチューブ (CNT) が生成する。

上述の説明からわかるように, ポリマーブレンド法の骨子は“デ ザインしやすいポリマーの段階でCPPの構造をデザインし，その 履歷を炭素化後に残す”ということである。したがって, CPP以 外のポリマーにも適用可能である。最後にポリカルボシランを 使用したナノ炭化ケイ素の例を簡単に紹介する。

\section{3. デザイニングの具体例}

\section{1 纎維軸に沿って配向した蓮根型細孔を有するカーボンファ} イバ

活性炭素繊維 (ACF) は, ヤシ殼炭などの通常の粒状活性炭 （GAC）とは異なる細孔構造を有する。GACがマク口孔（直径 $>50 \mathrm{~nm})$, メソ孔 $(2 \sim 50 \mathrm{~nm})$ およびミクロ孔 $(<2 \mathrm{~nm})$ などの広

- Corresponding Author, E-mail: jozaki@cee.gunma-u.ac.jp (平成20年5月2日受理, 平成20年6月9日採択) 群馬大学大学院工学研究科：=376-8515 群馬県桐生市天神田 1-5-1

Graduate School of Engineering, Gunma University : 1-5-1 Tenjin-cho, Kiryu, Gunma 376-8515, Japan 


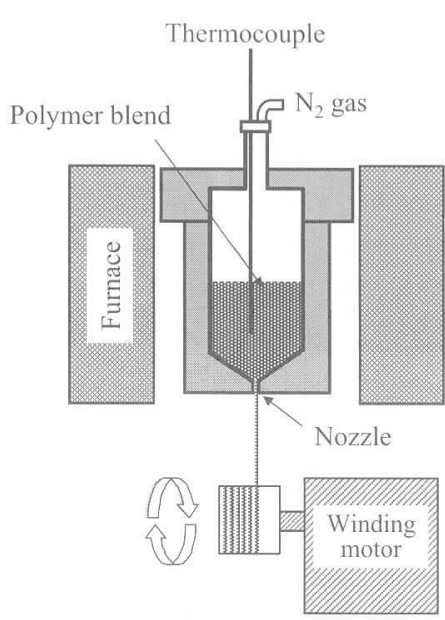

Fig.2 A schematic illustration of the continuous melt-spinning apparatus.

範なサイズの細孔を有するのに対して, ACFは外表面に直接露出 した大量のミクロ孔だけから構成される。ACFが大きな吸脱着 速度と, 大量の物質を吸着できるのはこの構造に起因する。

$\mathrm{ACF}$ は, 水蒸気や炭酸ガスを用いて $850^{\circ} \mathrm{C}$ 前後でカーボンファイ バ $(\mathrm{CF})$ を酸化 (賦活) して調製される。 $\mathrm{CF}$ の半分以上が消失す るこの賦活は, 非経済的なプロセスと言える。賦活を使用せずに $\mathrm{ACF}$ を調製できないか! この強い思いが, ポリマーブレンド法に よるナノカーボンのデザイニングの研究を始めた起点である。

TVPが微小分散したCPPをFig.2に示したような装置を用いて 紡系し, 不融化, 炭素化す机ば, CPPから誘導さ机るCF中に, TVP の消失した跡が細孔として残るはずである2!。細孔容積と細孔径 はブレンド比とブレンド構造のデザイニングによって制御できる ので3), 所望する細孔構造をもつACFを作ることができると考え た。ただし，このアイディアを具現化するには, CPPとTVPの残 炭の有無に加えて, 次のことも必要である。

ACFを調製するとなれば, 紡系は不可欠である。したがって, ポリマーブレンドは紡糸可能なものでなければならず, そのため には紡糸時における溶融粘度の近いCPPとTVPの組み合わせを 見つけ出すことが必要である。このことは紡系性の発現のみな らず,繊細なブレンド構造をデザインするうえでも重要である。

しかしながら, 実際に溶融粘度を測定することはそう簡単でな い。筆者らは溶融粘度の代わりに軟化点を使用しているが, これ までのところあまり不都合は感じていない。こうした要求項目 に基づいて, 最終的にCPPとして熱可塑性のノボラック型フェノ 一ル樹脂 $(\mathrm{PF})$ を, TVPにポリエチレン $(\mathrm{PE})$ を選択した。PE： $\mathrm{PF}=3: 7$ の割合で混練, 溶融紡糸, 硬化液中で不融化した後, 最 彴に $900{ }^{\circ} \mathrm{C}$ で2 時間炭素化した2)。

得られたCFは, Fig.3 (a)のような破断面を示す。最大でも直 径 $2 \mu \mathrm{m}$, 多くは1 $\mu \mathrm{m}$ からサブミクロンの多数の気孔が観察され た。Fig.3 (b) は破断した綫維側面のSEM写真である。蓮根状の 細長い気孔が繊維軸に沿って整然と配列しており,筆者らが当初 に想定した通常のACFの細孔構造とはまったく異質なものであ る。紡糸による延伸考えれば当然の帰納と言える。この多孔
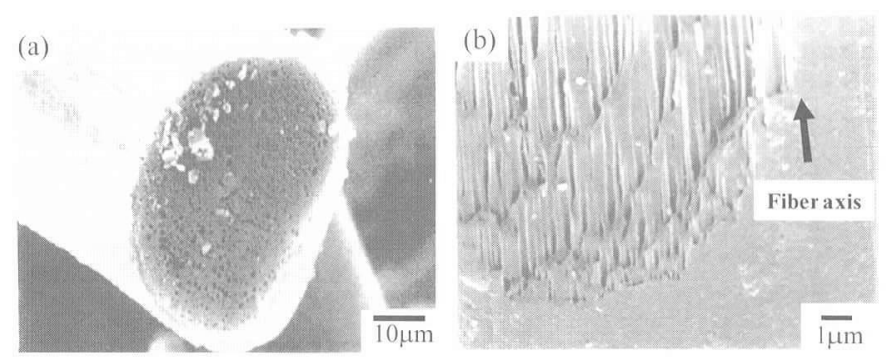

Fig.3 Carbon fiber containing (a) "lotus root" type pores, crosssections, and (b) broken side surface.

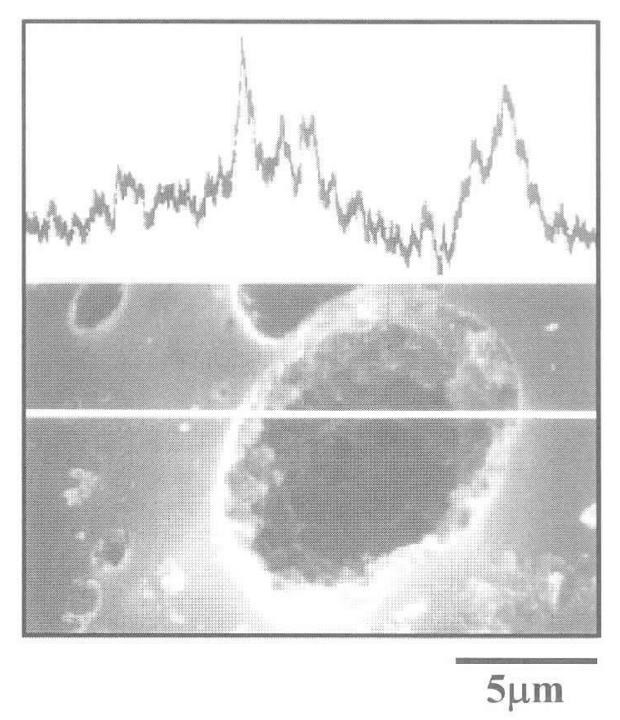

Fig.4 EPMA profile of Pt along the white line, shown in the SEM image.

質 CFをどう使うかはさておき,ポリマーブレンド法を用いてこ うしたユニークな細孔構造をもつCFをデザインできることを,ま ずもって知っていただきたい。

このう法は, 細孔表面上に金属粒子老選択的に担持することに も利用できる。TVP中にあらかじめ金属キレートを溶解させて おけば, TVPが分解消失した後に生じる細孔の表面上に, キレー トの分解によって生じた金属粒子が残存する。一例を紹介して おこう。

白金のアセチルアセトン錯体を分散したPEを, PF中に微小粒 子として分散させた後に紡系, 不融化, ついで炭素化すると, Fig.3 と同様に多数の蓮根型の細孔をもつCFが生成する。得られた試 料中に㧈ける白金の担持状態を検討するために, 電子線プローブ マイクロアナライザー(EPMA) をFig.4に示された線に沿って走 査させた。写真中で見られる細孔が大きいのは,EPMAの分解能 を考慮したためであり,多くの細孔はこれよりもはるかに小さい。 白金からの強いX線強度を示す位置がちょうど細孔の表面部分 に対応している。白金は細孔表面上に選択的に担持され,マトリ ックスカーボン中には存在しないことがわかる。

3.2 カーボンナノファイバ

3.2 .1 低結晶性カーボンナノファイバ

Fig.3で示した蓮根型細孔を有するCFの構造は, ポリマーブレ 


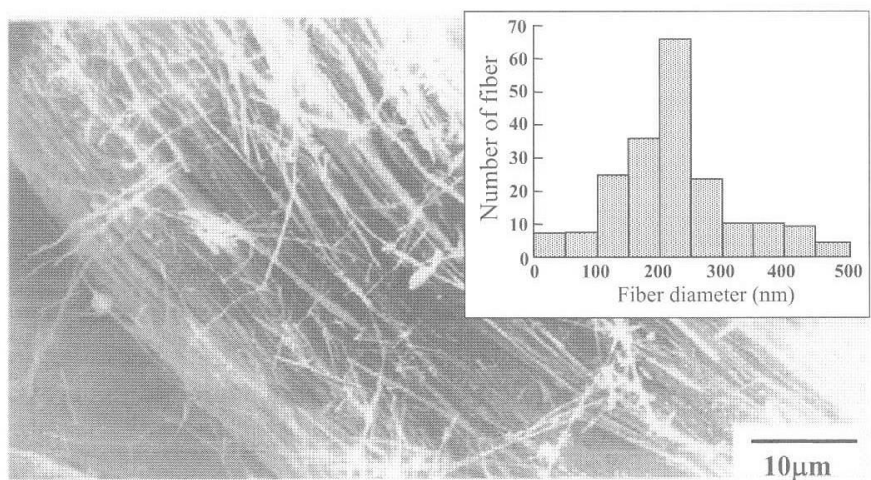

Fig.5 Typical image of a PF resin-derived CNF bundle and the diameter distribution histogram obtained from the image.
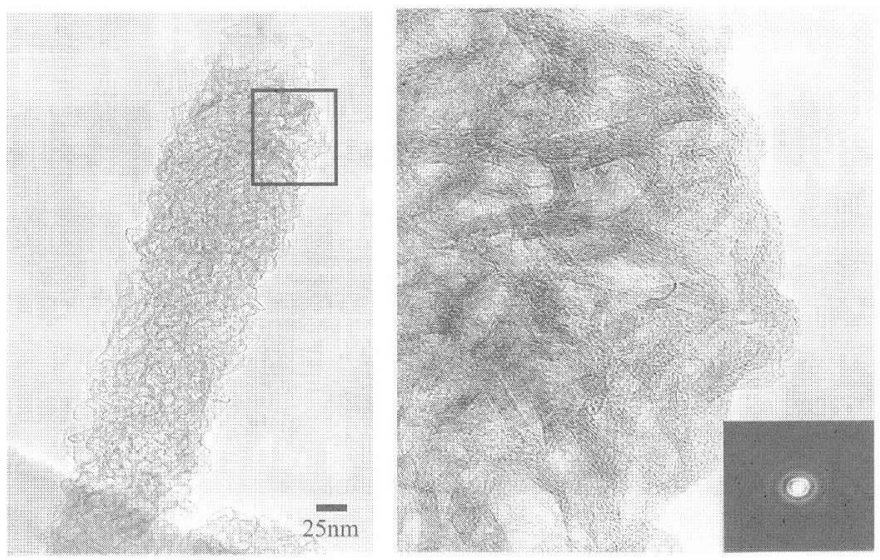

Fig.6 TEM photographs of a PF resin-derived CNF after heating at $3000^{\circ} \mathrm{C}$ and its SAED pattern.

ンド法でCNFを調製し得ることを示唆している。CPPとTVPの 混合比を逆にすれば, Fig.3の気孔の部分が炭素になる,すなわち CNFが生成する。噴霧法を用いて, $2 \mu \mathrm{m}$ 以下の微細な PF粒子を $\mathrm{PE}$ マリックス中にPF：PE = 3：7の割合で分散させ, 溶融紡 糸後に不融化,ついで $900{ }^{\circ} \mathrm{C}$ で 10 分間炭素化した。不融化繊維 の破断面には, 引き抜かれた多数のPFナノファイバが観察され， 炭素化後にはFig.5のようなCNFの束が生成した4)。

$\mathrm{PE}$ に対する $\mathrm{PF}$ 割合が増すと, 当然のことながら得られる CNFの束は密になる。CNFの生成効率を考えれば, $\mathrm{PF}$ の割合を できるだけ大きくしたい。ところが，PFの割合が増すと PF粒子 が融着しやすくなって, CNF径の増大やバラつきの原因になる。

CNFの径のヒストグラムを, 同じくFig.5に示した。バラつき が見られるものの，平均径はほぼ200～300 nmである。CNF径 を小さくするには, TVP中に分散するCPPの粒子径を小さくし， 紡糸時の延仲率を上げればよい。しかし二相構造のポリマーブ レンドは, 単一相のポリマーに比べて紡系性の低下は避けられず, こうした低下を抑制し得る手法の導入も必要である。

Fig.6は3000 C C゙処理したPF系 CNFのTEM写真である。繊 維表面は凹凸状であり,また難黒鉛化性炭素特有の絡まったりボ ン構造が観察される5)。一般に難黑鉛化性のCFは柔軟で可撓性 に優れるが, その反面で機械的強度や導電性は低い。こうした性
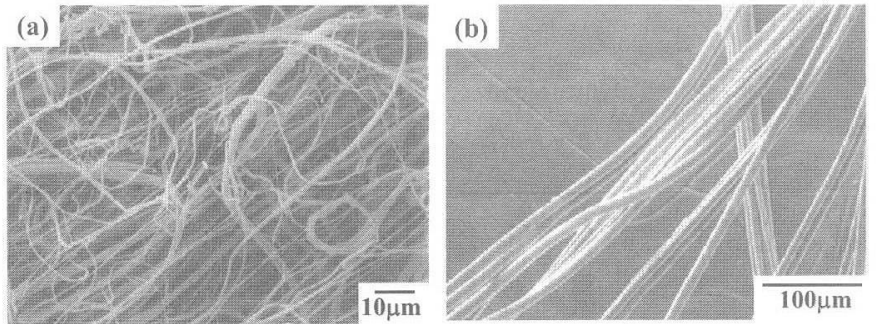

Fig.7 Comparison of the appearances of the AR resin-derived CNF by two different spinning techniques ; (a) melt-blow method, (b) continuous melt-spinning method.

質を活用する用途はそれなりに存在するのだろうがこここではこ の対極に位置する高結晶性CNFを次に紹介する。

3.2 .2 高結晶性カーボンナノファイバ

CNF 調製法としてのポリマーブレンド法の利点の1つは, 高結晶 性のCNFを調製できることであろう。紡系延伸時にTVPマトリ ックスにかかる剪断力が, 内包される CPP 粒子にも作用して構成 分子の配向性を向上させるためである。この際に, 配向しやすい $\mathrm{CPP}$ を原料に選択することはもちろん必要で,筆者らが選択した のはメソフェーズピッチである6)。通常のメソフェーズピッチは 軟化点が高いために紡系はそう簡単でないとされるが, $\mathrm{HF} / \mathrm{BF}_{3}$ 超 強酸触媒を用いてナフタレンを重合した AR 樹脂 (ピッチ)は, 軟 化点が低く格段に紡糸しやすい7)。

上述したように, 高い紡糸性を有するポリマーブレンドの調製に は, 軟化点の近いCPP と TVPの組み合わせが必要である。経済 性を考えれば問題はあろうが, AR 樹脂のパートナーとなるTVP としてポリメチルペンテン (PMP) を選択した6)。炭素残渣を生 じないという前提条件に加えて, 軟化点が $\mathrm{AR}$ 樹脂に近いことを

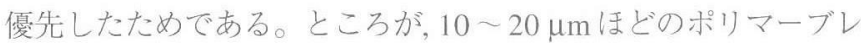
ンド繊維では, PMP中に内包されたAR樹脂繊維の空気不融化は きわめて難しい。紡系繊維を細くできれば, 内包 $\mathrm{AR}$ 樹脂繊維ま での酸素の拡散距離が短くなり, それだけ不融化は容易になるは ずである。同時に, 内包 $\mathrm{AR}$ 樹脂の緘維径も小さくなるだろう。

そこで筆者らは, 単孔のメルトブロー紡系装置を試作した6)。 この装置の特徵は, 加圧によって紡系孔から押し出された繊維が, 高速の加熱空気によって再延伸されることである。この装置と, Fig.2の連続溶融紡系装置を用いて紡系した繊維の写真を, 比較 のためにFig.7に示した。メルトブローでは数 $\mu \mathrm{m}$, 条件によって はサブミクロンの径の繊維の紡系も可能である。

調製されたメソフェーズ系 $\mathrm{CNF} 3000{ }^{\circ} \mathrm{C}$ で黒鉛化処理した。 そのTEM写真をFig.8 (a)に示した。直径はほぼ100 nmである。 Fig.8 (b) にこのCNTの格子像を示す。高い結晶構造が鮮明に見 てとれる。ちなみに,このCNFの $\mathrm{d}_{002}$ は $0.338 \mathrm{~nm}$, 結晶子の厚さ $\mathrm{Lc}(002)$ は $57 \mathrm{~nm}$ である。上市されている $\mathrm{CNF}$ として気相成長 炭素繊維 (VGCF) がよく知られている8)。150 nm径のVGCFの力 タログによれば, $\mathrm{d}_{002}$ が $0.339 \mathrm{~nm}, \mathrm{Lc}(002)$ は40 nmである。高結晶 性CNFを調製するうえでのポリマーブレンド法の有効性を知る ことができる。 

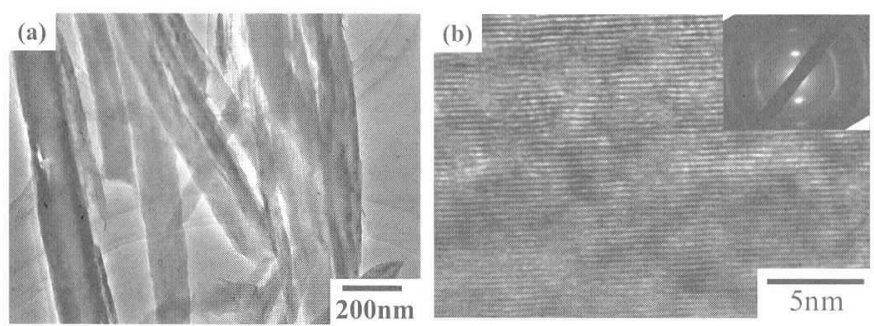

Fig.8 TEM images of the AR resin-derived CNF heat-treated at $3000{ }^{\circ} \mathrm{C}$; (a) bright field image, (b) lattice image with SAED pattern.

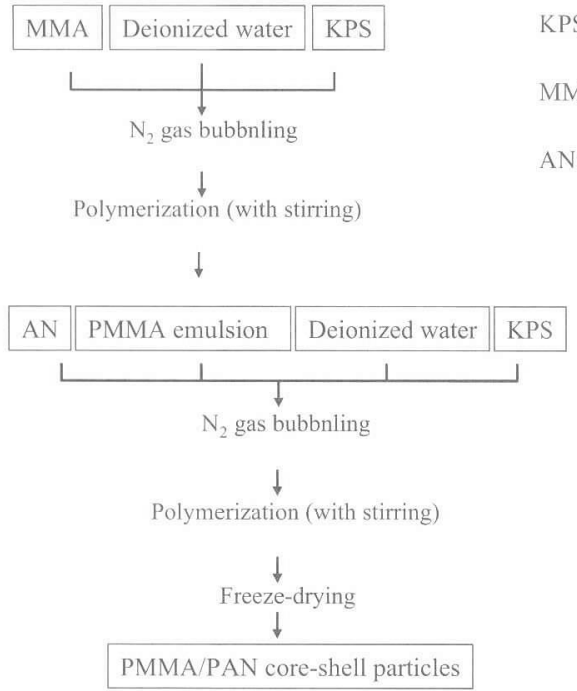

Fig.9 Preparation procedure of PMMA / PAN core - shell polymer particles.

\section{3 カーボンナノチューブ}

CNT は中空構造をもつ CNFである。CNF中に中空構造を導 入できさえすれば, ポリマーブレンド法を用いてCNTを調製でき るはずである。そのために考案されたアイディアは, Fig.1で示 したTVPコアとCPPシェルとからなるコアシェル型ポリマー粒 子の使用である9), 10)。

コアシェル粒子の調製は至って簡単である。いわゆる二段階 ソープフリー重合法を用いればよい。Fig.9に,コアにTVPのポ リメチルメタクリレート (PMMA), シェルとしてCPPのポリア クリロニトリル (PAN) を使用したコアシェル粒子の調製法を示 した。たた、調製されたコアシェル粒子をそのまま紡系すると， シェルのPAN同士が融着し, その結果, 融着状態のCNTが生成 することが懸念される。融着を回避するために,コアシェル粒子を さらにPMMA で被覆した。Fig.9のプロセスにMMAの重合プロ セスを加えればよい。

得られたコアシエル粒子のSEM写真をFig.10 (a) に示した。 $500 \mathrm{~nm}$ のきわめて均一な粒子である。コアシェル粒子を, Fig.2 の装置を用いて紡糸した繊維のSEM写真がFig.10 (b) である。

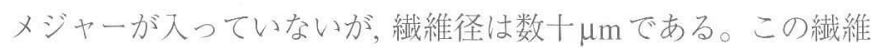
が, Fig.10(b) のモデル図のような内部構造を有するとすれば, 不

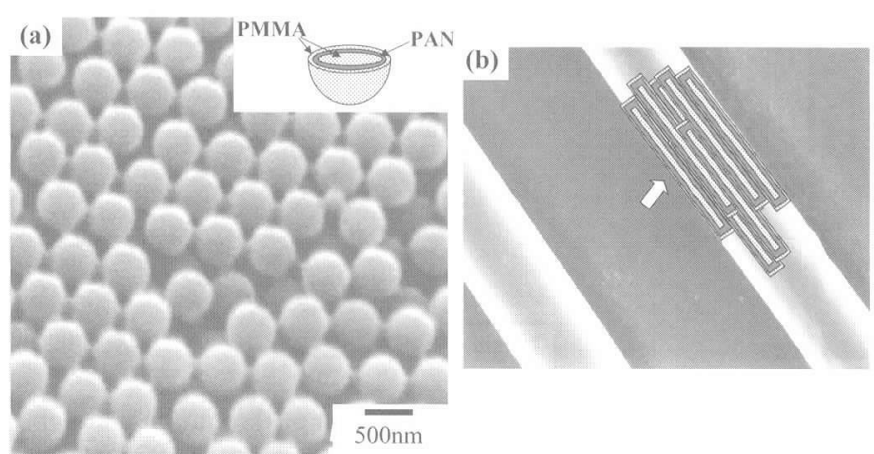

Fig.10 SEM photographs of the precursors at different preparation stages ; (a) the three layered core-shell particles and (b) the spun fibers. The superimposed picture on the fiber shown in (b) indicates our speculation how the threelayered particles are elongated by the spinning process.

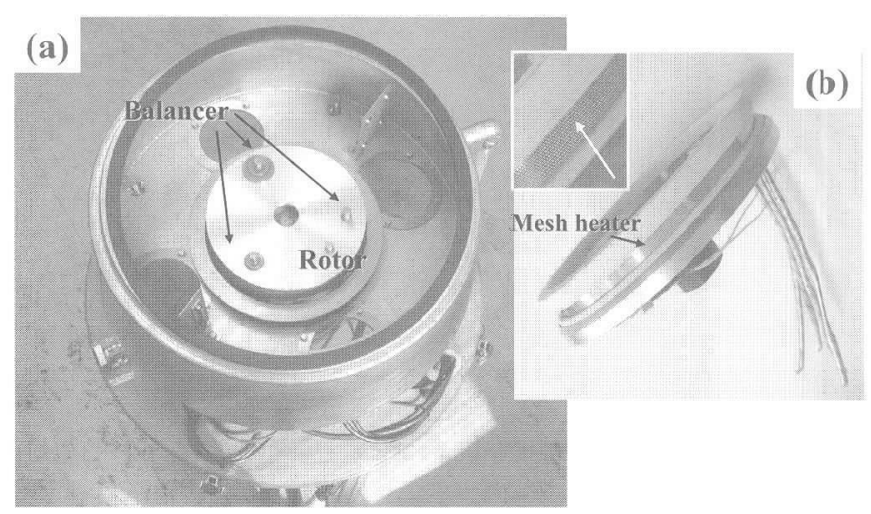

Fig.11 (a) The developed centrifugal spinning equipment. The maximum speed and the spinning temperatures were increased up to $6000 \mathrm{rpm}$ and $350^{\circ} \mathrm{C}$, respectively. (b) The improvements were enabled by the newly developed mesh heater.

融化，炭素化後にCNTの束が生成されると考えられる。ところ が現実にはCNTはほとんど生成しない。紡糸孔を通過する前の 溶融状態で, コアシェル粒子がPANとPMMAとに相分離するた めである。コアシェル粒子を相分離することなく紡系すること が, CNT調製の鍵である。

これに対して,2つの解決法が考えられる。1つは, 溶融状態で長 時間保持しても相分離しない安定なコアシェル粒子を調製する こと、ほかはコアシェル粒子が相分離する前に迅速に紡系すること である。前者の試みはうまくいかず, 後者を達成するための紡系装 置の開発が行われた。それが遠心紡糸装置である。Fig.11(a)は, 幾多の改良を加えた末に試作された装置の全体像で, 最大のポイ ントはFig.11 (b) に示した带状のメッシュヒーターにある11)。写 真で見られるメッシュの孔徍は0.5 mmめである。

ローターに取り付けた直径 $15 \mathrm{~cm}$ のメッシュヒーターのリング

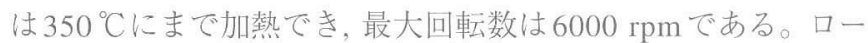
ター中央部の孔から投入されたコアシェル粒子はメッシュヒータ 一表面に運ばれて加熱され, 軟化溶融すると遠心力によって即座 

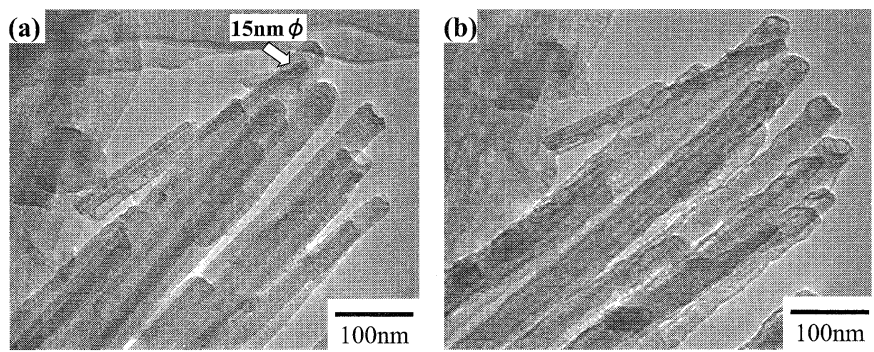

Fig.12 Electron beam induced deformation of the carbon nanotubes carbonized at $600{ }^{\circ} \mathrm{C}$. (a) The initial state of the CNT and (b) the deformed CNT by the electron beam irradiation for several minutes.

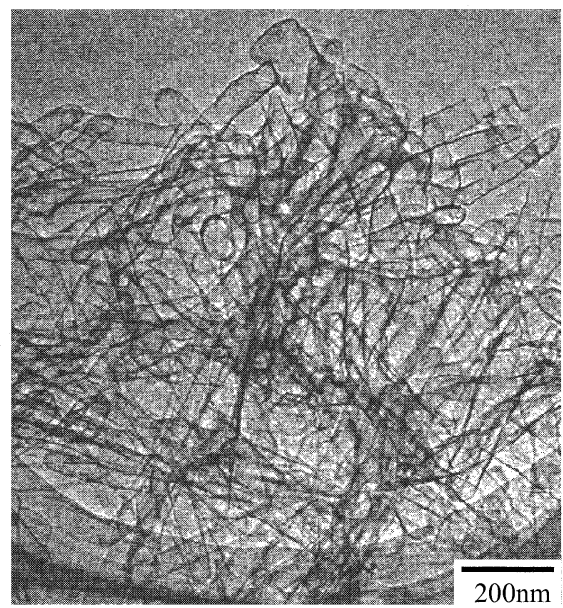

Fig.13 TEM micrograph of carbon nanotubes prepared by using the centrifugal spinning apparatus shown in Fig.11.

に紡糸される仕組みになっている。それでもCNTはまったくと 言ってよいほどに生成しなかった。Fig.12(a) は, Fig.11よりも いくぶん性能の低い初期の遠心紡糸装置を用いて調製されたCNT の束で, 丹念に観察した末にようやくにして見出されたもので ある。直線性に優れ，チューブの外径は数十 $\mathrm{nm}$, 最小のものは $15 \mathrm{~nm}$ で, CNTの中空構造は非常に細い。

さて,この研究が行われていた頃は, CNTの調製に関する論文 が数多く見られた。問題になったのは, CNT が銅グリット上の 炭素膜中にあらかじめ存在していたものではないかという疑念で

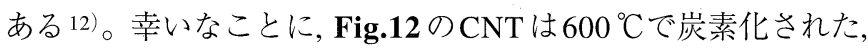
すなわち生焼き状態であった。そのためにTEM 観察中にFig.12 (b) のように変形し, このことがコアシェル型ポリマー粒子から 調製されたことの決め手になったのである。

Fig.11の改良型遠心紡糸装置で調製されたCNTを Fig.13に示 した。不融化が不完全であったために変形してはいるが，この視野 にはCNT 以外の不純物炭素はいっさい存在しない。こうした部 分が全体に占める割合は, 多く見積もってもせいぜい $10 \%$ 止まり である。しかしこのTEM写真は, ポリマーブレンド法の調製条 件を最適化することで, 高純度 CNTを量産し得る可能性を示唆 している点で重要である。

もう 1 つの興味は,こうして調製されたCNTの微視的構造であ
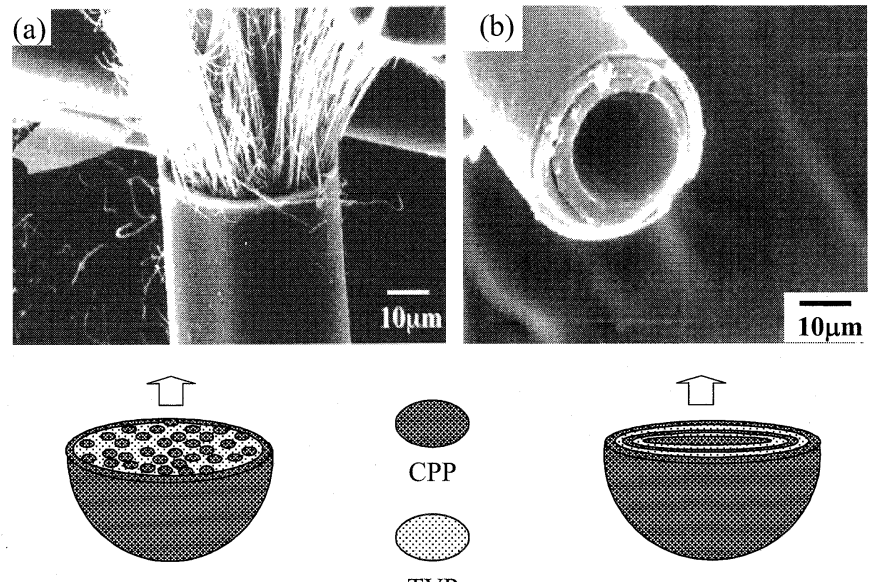

TVP

Fig.14 Two examples of unique carbon materials prepared by the polymer blend technique. The lower illustrations show the various types of the core-shell polymers for each unique structure.

る。これまで $1000{ }^{\circ} \mathrm{C}$ 以上に加熱したことはなく, 得られた CNT はすべて結晶性の低いものである。黒鉛化処理による構造変化 を検討したいのだが, 何分にも十分な量のCNTが得られていな い。そうしたわけで, CNT の収率向上が当面の課題となってい る。遠心紡糸法よりも低温, すなわち相分離しにくい高溶融粘度 で紡糸できるような装置についても研究を続けている。

蓮根型細孔表面への白金の選択的担持について上述したが,こ の手法はCNTにもそのまま適応できる。CNT内表面上への金属 粒子の選択担持の可能なことを付け加えておく。

\section{4 ユニークな形状のカーボン}

ポリマーブレンド構造を繊細に制御し得る技術が開発されれ ば,ささらに複雑な形状のカーボンのデザイニングが可能になる。 例えば, Fig.14 (a) は, 径が $40 \mu \mathrm{m}$ 前後のカーボンチューブで, 多 数のCNFを内包している2)。このユニークな材料は,下に示され ているコアシェル型ポリマー粒子の紡系で作られるはずである が,これまでのところ粒子を合成できていない。このカーボンは, 次のような“トリッキー”な方法で調製されたものである。微小 分散したPF粒子を内包するPEを連続溶融紡糸し,ついで紡系瀻 維をPFのメタノール溶液に通してPFで被覆する。乾燥後に不 融化, 炭素化した。筆者らの興味は, CNFを内包するこのカーボ ンチューブにポリマーを含浸して, CNF 補強䋐維を作ることであ る。一体どんな力学特性が発現するだろうか？

Fig.14（b）は多層カーボンチューブである。ただし, CNTでは なく $\mu \mathrm{m}$ サイズのカーボンチューブである。TVPの極細繊維表面 を, $\mathrm{PF}$ 樹脂のメタノール溶液とポリスチレン (PS) のトルエン溶 液を用いてPF層とPS層で交互に被覆し, 不融化, 炭素化して作 られた。下に示すコアシェル粒子を調製できれば, 紡糸だけでこの カーボンチューブの調製は可能だろう。

$2 つ の$ づザイニングの例を示した。ポリマーブレンド法は, ア イディア次第でさまざまな形状のカーボンをデザイニングし，調 製し得ることを拉わかりいただけたと思う。 


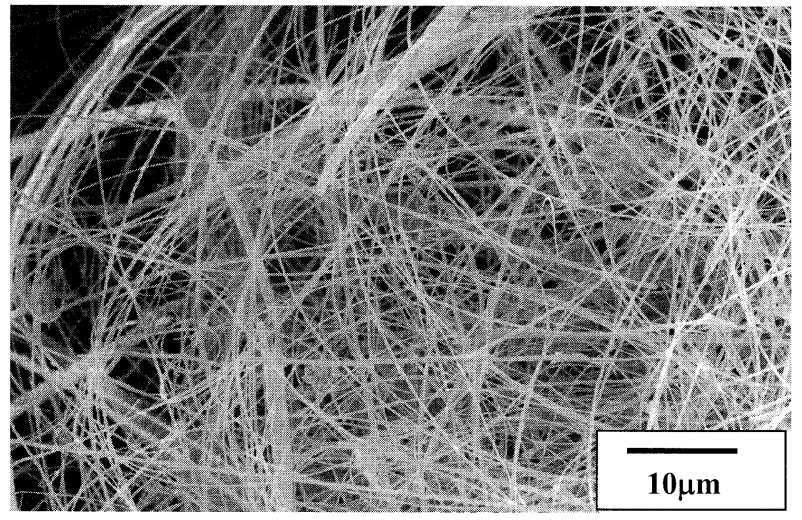

Fig.15 Application of the polymer blend technique to the preparation of silicon nanofibers with polycarbosilane.

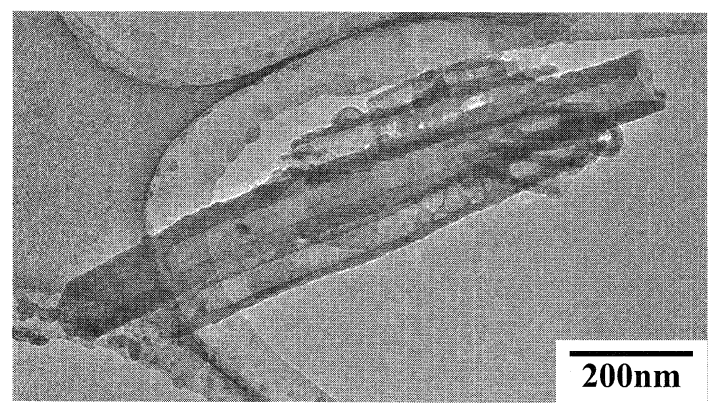

Fig.16 Hetero-double-walled tubular structure by applying the polymer blend technique. The inner wall is carbon and the outer one is silicon carbide.

\section{5 他材料への適用}

炭化ケイ素の前駆体として知られるポリカルボシラン (PCS) は, 加熱により軟化溶融し, 空気酸化や電子線照射により不融化 することができる13)，14)。したがって，ナノカーボンの場合とま ったく同じ手法で, 多様な形状のナノ炭化ケイ素を調製できる。 PCS から調製される試料の化学量論は厳密には“SiC”でないが, ここでは紛らわしさを避けるために炭化ケイ素と呼ぶことにす る。2つのデザイニングの例を簡単に紹介する。

最初は炭化ケイ素ナノファイバである。ここでは上述した CNF の調製に用いた方法を，そのまま使用することはできなかった。 PCS の不融化が難しいために, 得られるナノファイバが融着するか らである15)。

炭化ケイ素は, 炭素に比べて高い耐酸化性を示す。PCS から誘 導される炭化ケイ素も同様である。TVPの代わりにCPPである $\mathrm{PF}$ をトリックスポリマーに使用すると, $1000{ }^{\circ} \mathrm{C}$ 程度の熱処理 後には, PFから生じる炭素マトリックス中に, PCS からのナノフ アイバが内包された繊維が得られる。炭化ケイ素ナノファイバ は, 炭素マトリックスに比べて耐酸化性が高いので, 得られた繊 維を酸化, 例えば硝酸酸化すれば, マトリックス炭素が選択的に 消失して炭化ケイ素ナノファイバが遊離してくる。

Fig.15はこの方法によってPCSから調製した炭化ケイ素ナノ ファイバである。径は数百 $\mathrm{nm}$ 前後で, 大きなアスペクト比を有
する長いナノファイバである。PCS から調製される炭化ケイ素 繊維の高温強度は, 酸素の導入量が増すにつれて低下することが 知られている16)。可能な限り酸素の導入されない条件で酸化処 理することが必要である。

次の例は, 内外側がそれぞれ炭素と, PCS 由来の炭化ケイ素と から構成される一種の複合ナノチューブである。Fig.16にTEM 写真を示した。この複合ナノチューブは,コアのPMMA粒子上 にPANシェル, さらにその上をPCSで被覆したコアシェル粒子 から調製されたものである。局所元素分析から, 複合ナノチュー ブであることを確認した。このナノチューブは通常のCNTに比 べて, 優れた耐酸化性を示すことが期待される。ただし, 原料コ アシェル粒子の調製法から再考しないことには高い収率は望む べくもなく,このままでは今後の展開は期待できそうにない17)。

\section{4. ポリマーブレンド法の利点と問題点}

ポリマーブレンド法の利点と問題点をお気づきになられたか と思うが, 最後にそれらを整理しておくことにしよう。先に利点か ら述べる。

i ）多様な形状のナノカーボンのデザイニングが可能で, このこ

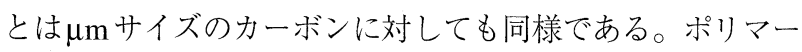
ブレンド構造の制御技術の発展によって複雑なブレンド構 造の構築が可能になれば18), 19), 形状の多様化は一層拡大す るはずである。

ii）構造を制御しやすい。触媒化学気相析出法 (CCVD法) のよ うな気相法では, 生成物が瞬時に生じるので構造制御は容易 でない。一方, ポリマーブレンド法はいくつかの独立したプ ロセスから構成され，それぞれのプロセスごとに確実な構造 制御が可能である。CNTの例で言えば, (1)コアポリマーとシ エルポリマーの混合割合, (2)重合条件, (3)巻き取り速度をは じめとする紡糸条件などであり，これら因子を組み合わせる ことにより, CNTの繊細な構造制御が可能になる。

iii）不純物含有量が少ない。上述したCNTのように, 現時点で は収率がわずかに $10 \%$ 程度で, 大部分が不純物炭素というも のもある。しかし, Fig.1のスキームどおりにプロセスが淮め ば, 不純物はいっさい生成しないはずである。一方の気相法で は, 不純物炭素の生成は避けられず20), この不純物除去が容 易でないことはよく知られている。

iv）量産に適する。ポリマーブレンド技術は, ポリマーの分野で は量産に使用されている沉用技術である。紡系, 不融化, 炭 素化も量産技術として現在工業的に使用されている。

v ）炭化ケイ素のような他材料に適応でき，また複合ナノ材料の 調製にも利用できる。

逆にポリマーブレンド法が幾多の問題点を含むのも事実であ る。その主なものは,

i ) 構成ポリマーの残炭生成の有無に加えて, 不融化や炭素化の 過程で両ポリマー間の反応によって熱的挙動の変化しない ことが必須条件である。また繊細なポリマーブレンド構造 を構築するには, 軟化点の近いCPP とTVPの組み合わせが不 
可欠である。こうした要求項目をすべて満足するポリマー の組み合わせを見出すことは, そう簡単なことではない。

ii ）上述したように, TVPマトリックス中に埋包されたCPPの不 融化が難しい。解決策としては, 高いガス透過性を有する TVPの使用, ブレンド試料の外表面積を可及的に大きくする, すなわち微小化すること, 強力な不融化試剤の使用 21$)$, など がある。効果的な不融化法の開発が, ポリマーブレンド法の今 後の発展の成否を決する鍵と言ってもよいだろう。

iii）量産化を想定すると,TVPに関する問題の発生が想定され る。低結晶性CNFの例で言えば, マトリックスとして使用す るPEの処理である。炭素化過程で炉内に大量に滞留するPE をどう取り除くか, またTVPの使用がナノカーボン製品の価 格を押し上げることは言うまでもない。できるだけ安価な TVPの使用が望まれる。

iv）微小化に限界？ ポリマーブレンドの紡糸においては,小さな CPP粒子ほど剪断力を受けにくい。すなわち延伸率が小さく なる。したがって, 繊維径の細さに限界があるかもしれない。

\section{5. おわりに}

ポリマーブレンド法によるナノカーボン, 一部はミクロカーボ ンのデザイニング例について紹介した。若干厳密を欠いた雑駁 な内容ではあるが, ナノカーボンをデザイニングするうえでのポ リマーブレンド法の有効性や面白さを, 何とかご理解いただけたか と思う。デザイニング例の詳細は引用文献をご覧いただきたい。 この類の研究は,工業化されてなんぼの世界である。実を言え ば, 上述したナノカーボンの中には, 企業化研究の対象になった ものもある。しかしながら，いまだに量産化には至っていない。 大学の研究室レベルの研究では見えなかった問題点が多々現れ てくるためである。そうかといって的確なアドバイスをすること もできないでいる。何とも歯がゆいが, 改めて工業化, スケール アップの難しさを痛感している。大学は“シーズを提供すればよ い”ということだけではすまされないのが昨今の風潮のようにも
見える。これまでは，もっぱらこの研究がもつ“パズル的”な面白 さを満喫してきたが, そろそろ軌道修正を考えなければならない 時期なのかもしれないと考えている。

\section{文 献}

1) L. H. Peebles, Carbon Fibers (1995) CRC Press.

2) N. Patel, K. Okabe and A. Oya, Carbon, 40 (2002) 315-320.

3) A. Oya, N. Kasahara and R. Horigome, J. Mater. Sci. Lett., 20 (2001) 409-411.

4) A. Oya and N. Kasahara, Carbon, 38 (2000) 1141-1144.

5) G. M. Jenkins and K. Kawamura, Polymeric Carbons (1976) Cambridge University Press.

6) H. Ono and A. Oya, Carbon, 44 (2006) 682-686.

7) I. Mochida, K. Shimizu, Y. Korai, H. Otsuka and S. Fujiyama, Carbon, 26 (1988) 843-852

8) M. Endo, Chemtech, 18 (1988) 568-576 [in Japanese].

9) D. Hulicova, K. Hosoi, S. Kuroda, H. Abe and A. Oya, Adv. Mater., 14 (2002) 452-455.

10) D. Hulicova, K. Hosoi, S. Kuroda, A. Oya and H. Abe, Mol. Cryst. Liq. Cryst., 388 (2002) 107-112.

11) T. Sandou and A. Oya, TANSO, 2006 [No.225] 344-346 [Japanese].

12) P. J. F. Harris, Carbon, 39 (2001) 909-913.

13) S. Yajima, Y. Hasegawa, J. Hayashi and M. Iimura, J. Mater. Sci., 23 (1978) 2569-2576.

14) A. Idesaki, M. Narisawa, K. Okamura, M. Sugimoto, S. Tanaka, Y. Morita, T. Seguchi and M. Itoh, J. Mater. Sci., 36 (2001) 5565-5569.

15) N. Patel, R. Kawai and A. Oya, J. Mater. Sci., 39 (2004) 691-693.

16) T. Shimoo, I. Tsukada, M. Narisawa, T. Seguchi and K. Okamura, $J$. Ceram. Soc. Japan, 105 (1997) 559-563.

17) Z. Correa, T. Sandou, C. Ida and A. Oya, TANSO, 2006 [No.226] 336-339.

18) P. Cassagnau and A. Michel, Polymer, 42 (2001) 3139-3152.

19) I. Luzinov, C. Pagnoulle and R. Jerome, Polymer, 41 (2000) 3381-3389.

20) Y. S. Park, Y. C. Choi, K. S. Kim, D. C. Chung, D. J. Bae, K. Y. An, S. C. Lim, X. Y. Zhu and Y. H. Lee, Carbon, 39 (2001) 655-661.

21) Y. Tanabe, F. Tanaka, M. Takahashi, T. Iiyama, N. Miyajima, S. Fujisawa and E. Yasuda, Carbon, 42 (2004) 1555-1564. 